\title{
UJI EFEKTIVITAS SALEP EKSTRAK DAUN JARAK PAGAR (Jatropha curcas L.) TERHADAP PENYEMBUHAN LUKA SAYAT PADA TIKUS PUTIH JANTAN GALUR WISTAR (Rattus norvegicus)
}

\section{EFFECTIVENESS TEST OF Jatropha curcas L. LEAF EXTRACT OINTMENT FOR WOUND HEALING IN MALE WHITE RATS WISTAR STRAIN (Rattus norvegicus)}

\author{
Repatri A. Bawotong ${ }^{1)}$, Edwin de Queljoe ${ }^{1)}$, Deby A. Mpila ${ }^{1)}$ \\ ${ }^{1)}$ Program Studi Farmasi FMIPA UNSRAT Manado, 95115
}

\begin{abstract}
Jatropha leaves (Jatropha curcas L.) contains alkaloid, saponin, tannin, terpenoid, steroid, glycoside, phenol compound and flavonoid through ethanol extract. Until today the community still used the plant as a wound healing medicine. The aim of this study is to examine the effectiveness of jatropha curcas L. leaf extract ointment for healing in male white rats wistar strain. Jatropha leaves extract ointment was tested on 5 which consists of 3 rats in each treatment groups, that is base ointment (negative control), ointment betadine (positive control), ointment extract of Jatropha leaves 10\%, 20\% and 40\%. Observations has made until the 14th day. And data were tested using ANOVA (Analysis of Variants) and continued with LSD (Least Significant Different) test. Statistical test results showed a difference in the duration of wound healing in male white rats wistar strain between the ointment extract of jatropha leaf with ointment betadine and vaseline ointment.
\end{abstract}

Keywords: Ointment, Jatropha extract (Jatropha curcas L.), Galur wistar, Wound.

\begin{abstract}
ABSTRAK
Daun jarak pagar (Jatropha curcas L.) mengandung zat-zat alkaloid, saponin, tannin, terpenoid, steroid, glikosida, senyawa fenol dan flavonoid melalui ekstrak etanol. Hingga saat ini masyarakat masih menggunakan tanaman tersebut sebagai obat penyembuh luka. Penelitian ini bertujuan untuk menguji efektivitas salep ekstrak etanol daun jarak pagar terhadap penyembuhan luka sayat pada tikus putih jantan galur wistar. Salep ekstrak daun jarak pagar diujikan pada hewan uji tikus sebanyak 5 yang terdiri dari 3 ekor tikus disetiap kelompok perlakuan, yaitu basis salep (kontrol negatif), salep betadine (kontrol positif), salep ekstrak etanol daun jarak pagar 10\%, 20\% dan 40\%. Pengamatan dilakukan sampai hari ke 14. Data diuji dengan menggunakan ANOVA (Analisis Of Variant) dan dilanjutkan dengan uji LSD (Least Significant Different). Hasil uji statistik menunjukan adanya perbedaan terhadap lamanya penyembuhan luka pada tikus putih jantan galur wistar antara sediaan salep ekstrak daun jarak pagar dengan salep salep betadine dan basis salep.
\end{abstract}

Kata Kunci: Salep, Daun jarak pagar (Jatropha curcas L.), Galur wistar, Luka sayat. 


\section{PENDAHULUAN}

Luka merupakan suatu keadaan, dimana jaringan tubuh mengalami kerusakan yang disebabkan beberapa faktor seperti trauma, gigitan hewan, goresan benda tajam dan lainnya. Ada 2 macam luka berdasarkan penyebabnya, yaitu luka terbuka dan tertutup. Salah satu contoh dari luka terbuka adalah insisi atau biasa disebut dengan luka sayat dimana keadaanya adalah terdapat robekan pada kulit dan jaringannya (Pusponegoro, 2005). Luka adalah masalah yang dianggap ringan dan sering dialami setiap orang. Padahal luka dapat menyebabkan infeksi (Atik, 2009). Oleh karena itu, penyembuhan luka sangat penting untuk mencegah resiko terjadinya infeksi yang dapat membuat luka menjadi parah dan sulit untuk disembuhkan.

Salep merupakan salah satu bentuk sediaan semi padat yang banyak digunakan dalam pengobatan kulit. Sebelum memberikan efek, zat aktif sediaan salep harus dapat dilepaskan dari basisnya, baru diabsorpsi melalui kulit. Hal ini dipengaruhi oleh beberapa faktor, baik faktor fisiologis maupun kimia fisika. Faktor kimia fisika tersebut meliputi koefisien difusi, konsentrasi dan kelarutan obat dalam basis. Sedangkan faktor fisiologi meliputi keadaan kulit, luas daerah permukaan dan banyaknya pemakaian (Anief, 2003).

Indonesia merupakan sebuah negara yang dikenal dengan kekayaan hayati yang berlimpah, dimana di dalamnya terdapat banyak sekali tanaman yang dapat dimanfaatkan sebagai obat, karena mereka percaya bahwa obat-obat yang berasal dari bahan alam jarang menimbulkan efek yang merugikan dengan resiko efek samping yang relatif kecil. Salah satu tanaman obat yang digunakan masyarakat Indonesia yaitu daun jarak pagar (Jatropha curcas. L) (Backer dan Brink, 1965). Menurut Agbogidi dkk (2013), tanaman ini mudah di dapatkan dan hingga saat ini masyarakat masih menggunakan tanaman tersebut sebagai obat penyembuh luka.

Menurut Syamsuhidayat (2002), daun jarak pagar banyak mengandung senyawa metabolit sekunder yang merupakan senyawa aktif. Seperti saponin, flavonoid, dan polifenol, daunnya juga mengandung tannin. Penelitian lainnya yang dilakukan oleh Sharma dkk (2012), diperoleh hasil bahwa daun jarak pagar mengandung zat-zat alkaloid, saponin, tannin, terpenoid, steroid, glikosida, senyawa fenol dan flavonoid melalui ekstrak etanol. Menurut Suharmiati dan Handayani (2005), daun jarak pagar berkhasiat sebagai obat cacing, perut kembung, dan luka. Hal ini terbukti dari kebiasaan masyarakat yang sering menggunakan daun jarak pagar untuk mengobati masalah kesehatan di atas.

Pada penelitian sebelumnya yang dilakukan oleh Mashita Andiana yaitu pemberian getah tanaman jarak pagar (Jatropha curcas L.) terhadap penyembuhan luka sayat pada mencit (Mus musculus) diperoleh hasil getah dari tanaman jarak pagar (Jatropha curcas L.) dapat mempercepat penutupan pada luka. Namun belum ditemukan pemanfaatan bagian daun dari tanaman tersebut sebagai penyembuhan luka. Oleh karena itu, peneliti menganggap bahwa penelitian tentang "Uji efektitivas salep ektrak daun jarak pagar (Jatropha curcas L) terhadap penyembuhan luka sayat pada tikus putih jantan galur wistar (Rattus novergicus)" perlu dilakukan.

\section{METODOLOGI PENELITIAN}

\section{Waktu dan Tempat Penelitian}

Penelitian ini dilakukan di Laboratorium Farmakologi Program Studi Farmasi, Fakultas Matematika dan Ilmu Pengetahuan Alam, Universitas Sam Ratulangi Manado periode November 2019 Juli 2020. 


\section{Bentuk Penelitian}

Jenis penelitian ini ialah penelitian eksperimen laboratorium dengan menggunakan Rancangan Acak Lengkap (RAL). Hewan uji dikelompokan dalam 5 kelompok masing-masing terdiri dari 3 ekor hewan uji.

\section{Alat dan Bahan}

\begin{abstract}
Alat
Alat yang digunakan dalam penelitian ini, antara lain: cutter, gunting, penggaris, perlak/alas, beaker, hot plate, oven, blender, kamera, sarung tangan, masker, kertas saring, ayakan, kapas, pencukur bulu, timbangan analitik, lumpang dan alu, wadah salep dan kandang tikus.
\end{abstract}

\section{Bahan}

Bahan yang digunakan dalam penelitian ini, antara lain: tikus putih jantan galur wistar (Rattus novergicus) 15 ekor, ekstrak daun jarak pagar (Jatropha curcas. L), alkohol $70 \%$, eter, vaselin putih, etanol $70 \%$, Salep Betadine. Pangan tikus putih (Rattus novergicus) berupa pellet atau sejenisnya

\section{Prosedur Penelitian}

\section{Penyiapan dan Pengambilan Sampel}

Tahap awal dilakukan dengan pengumpulan bahan baku daun jarak pagar (Jatropha curcas L.) yang diambil di sekitaran kota Manado. Daun tanaman jarak pagar dibersihkan terlebih dahulu dari kotoran yang menempel, kemudian dicuci dengan air mengalir sampai bersih lalu kemudian dikeringkan dengan cara dianginanginkan (Wardani dan Rachmania, 2017). Setelah kering daun jarak pagar ditimbang dan selanjutnya diserbukkan, kemudian ditimbang beratnya. (Wijaya dkk, 2014).

\section{Pembuatan Ekstrak Daun Jarak Pagar (Jatropha curcas L.)}

Menurut Qomariyah (2014); Wijaya dkk, (2014); Selvaraj dkk, (2015); Wardani dan Rachmania, (2017), ekstraksi dilakukan dengan memasukkan serbuk simplisia ke dalam bejana maserasi kemudian ditambahkan etanol $70 \%$ sampai seluruh serbuk simplisia terendam. Diaduk dan didiamkan selama $5 \times 24$ jam. Disimpan pada suhu ruang dan terlindung dari cahaya. Selama perendaman dilakukan beberapa kali pengadukan. Setelah 5 hari, Ampas yang diperoleh dari penyaringan diremaserasi dengan etanol $70 \%$ dengan prosedur yang sama, maserasi dilakukan selama 2 hari dan di oven pada suhu $40^{\circ} \mathrm{C}$. Kemudian diperoleh ekstrak kental.

\section{Pembuatan Salep Dengan Ekstrak Daun Jarak Pagar (Jatropha curcas L.)}

Tabel 1. Formula salep dari tanaman jarak pagar (Jatropha curcas L.)

\begin{tabular}{lccc}
\hline \multirow{2}{*}{ Jenis } & \multicolumn{3}{c}{ Bahan (gram) } \\
\cline { 2 - 4 } & $10 \%$ & $20 \%$ & $40 \%$ \\
\hline $\begin{array}{l}\text { Ekstrak daun jarak } \\
\text { pagar }\end{array}$ & 1 & 2 & 4 \\
Vaselin putih & 9 & 8 & 6 \\
\hline
\end{tabular}

Pembuatan salep ekstrak daun jarak pagar (Jatropha curcas L.), dengan konsentrasi 10\%, 20\% dan 40\%. Basis salep ditimbang sesuai yang diperlukan (Rahmawati dkk, 2009). Lalu dimasukan kedalam cawan dan dileburkan diatas penangas air hingga meleleh (Sari dan Maulidya, 2016). Kemudian diaduk sampai dingin lalu ditimbang sesuai yang dibutuhkan dan tambahkan dengan ekstrak daun jarak pagar (Jatropha curcas L.) sedikit demi sedikit hingga tercampur menjadi satu. Kemudian dimasukkan dalam wadah salep (Rahmawati dkk, 2009). 


\section{Hewan Uji}

Penelitian ini menggunakan tikus putih (Rattus norvegicus) sebagai hewan uji yang diadaptasi dengan lingkungan selama 7 hari dan terbagi dalam 5 kelompok dimana masing-masing kelompok terdiri atas 3 ekor tikus putih yang dipelihara dalam kandang yang terpisah dimana satu kandang berisi satu tikus dan diberi pangan berupa pellet dan beras milu.

\section{Pembuatan Luka Sayatan Pada Tikus}

Pembuatan luka pada tikus menurut Asadi dkk (2013) dilakukan dengan langkah sebagai berikut:

1. Melakukan anestesi dengan menggunakan eter.

2. Tunggu 5-10 menit sampai obat bius bereaksi

3. Menghilangkan rambut pada punggung dengan cara mencukurnya menggunakan gunting dan pencukur, tujuannya untuk mempermudah pada saat melukai, pemberian perlakuan dan pengamatan.

4. Memasang perlak dan alasnya dibawah tubuh tikus yang akan dilukai.

5. Melakukan disinfeksi area kulit yang telah dicukur dengan alkohol $70 \%$.

6. Melakukan penyayatan kulit menggunakan cutter steril dengan kedalaman $0,3 \mathrm{~cm}$ dengan panjang $1 \mathrm{~cm}$ (Rairisti, Wahdaningsih, dan Wicaksono, 2014). 5 menit setelah dilakukan perlakuan sayatan pada hewan uji, selanjutnya ekstrak daun jarak pagar dioleskan secara merata pada permukaan luka selama 14 hari pengujian.

\section{Perlakuan Terhadap Hewan Coba}

Kelompok I adalah kelompok kontrol negatif, yaitu kelompok tikus dengan luka yang diberi vaseline putih (basis salep), kelompok II adalah kelompok tikus dengan luka sayat yang diberi perlakuan penyembuhan menggunakan salep salep betadine sebagai kontrol positif, kelompok III adalah kelompok tikus dengan luka sayat yang diberi perlakuan penyembuhan menggunakan salep ekstrak daun jarak pagar (Jatropha curcas L.) dengan dosis 10\%, kelompok IV adalah kelompok tikus dengan luka sayat yang diberi perlakuan penyembuhan menggunakan salep ekstrak daun jarak pagar (Jatropha curcas L.) dengan dosis $20 \%$ dan kelompok $\mathrm{V}$ adalah kelompok tikus yang diberikan salep ekstrak daun jarak pagar (Jatropha curcas L.) dengan dosis $40 \%$ (Qomariyah, 2014).

\section{Perawatan Luka}

Menurut Qomariyah (2014) perawatan luka dilakukan dengan cara sebagai berikut:

1. Mencuci tangan dan memasang sarung tangan.

2. Menempatkan perlak yang dilapisi kain dibawah tikus yang akan dirawat.

3. Mengatur posisi tikus senyaman mungkin sehingga memudahkan tindakan perawatan.

4. Mengecek keadaan luka dengan melihat ada tidaknya eritema, pembekakan dan luka menutup.

5. Memberikan pengobatan pada masingmasing kelompok perlakuan.

6. Pengobatan dilakukan $2 x /$ hari dan diberikan sebanyak 0.07 gram

\section{Tahap Pengamatan}

Pengamatan dilakukan dengan cara melihat lama penyembuhan dari tiap-tiap perlakuan dan kontrol. Parameter pada penelitian ini yaitu, dengan melihat adanya eritema, pembengkakan, dan luka menutup (Andiana, 2018).

\section{Analisis Data}

Data dianalisis dengan mengelolah data secara statistik menggunakan SPPS versi 25. 
Uji Homogenitas dan Normalitas dilakukan dengan Uji ANOVA dilanjutkan dengan Uji LSD dengan taraf kepercayaan $95 \%$.

\section{HASIL DAN PEMBAHAS}

Dalam penelitian ini, observasi terhadap penyembuhan luka sayat pada tikus putih jantan galur wistar dilakukan secara makroskopis, dimana bertujuan untuk membandingkan penyembuhan luka sayat antara 5 kelompok dengan intervensi yang berbeda. Pengamatan kondisi luka sayat dilakukan sampai luka sembuh yang dilihat dari ada tidaknya eritema, pembengkakan dan luka menutup. Hasil pengamatan luka sayat pada tikus putih jantan galur wistar dapat diamati pada tabel 2.

Tabel 2. Pengamatan hari kesembuhan luka sayat

\begin{tabular}{cccccc}
\hline \multirow{2}{*}{ Tikus } & \multicolumn{5}{c}{ Waktu (hari) } \\
\cline { 2 - 6 } & Kel 1 & Kel II & Kel III & Kel IV & Kel \\
& V & & & & \\
\hline $\mathbf{1}$ & 16 & 25 & 11 & 11 & 11 \\
$\mathbf{2}$ & 15 & 24 & 9 & 10 & 8 \\
$\mathbf{3}$ & 14 & 9 & 8 & 9 & 7 \\
\hline Rerata & 15 & 19.3 & 9.3 & 10 & 8.6 \\
\hline
\end{tabular}

Keterangan: Kel I (Luka sayat diberi Vaseline putih), Kel II (Luka sayat diberi salep Betadine), Kel III (Luka sayat diberi salep ekstrak daun jarak pagar $10 \%$ ), Kel IV (Luka sayat diberi salep ekstrak daun jarak pagar 20\%) dan Kel V (Luka sayat diberi salep ekstrak daun jarak pagar 40\%)

Berdasarkan tabel tersebut dapat dilihat perbedaan rerata waktu (hari) yang dibutuhkan oleh setiap kelompok tikus untuk menutupnya luka. Pada tabel dapat diamati ketiga tikus dikelompok I mengalami penutupan luka secara berurutan dimulai dari hari ke 14 sampai hari ke 16. Berdasarkan perhitungan rerata waktu penyembuhan luka sayat pada kelompok I dasar salep (kontrol negatif) membutuhkan waktu rerata 15 hari. Kelompok II menggunakan salep betadine (kontrol positif) sebagai pengobatan yang menunjukkan hasil yang sangat jauh berbeda dengan perlakuan pada ekstrak daun jarak pagar, rerata waktu yang dibutuhkan agar luka sayat dapat menutup pada kelompok II yaitu 19 hari. Sedangkan pada salep ekstrak daun jarak pagar dengan konsentrasi $10 \%$ memiiliki rerata waktu 9.3 hari dan 10 hari untuk konsentrasi $20 \%$ dan 8.6 hari untuk konsentrasi $40 \%$.

Hasil pengamatan kondisi luka dilihat dari ada tidaknya eritema (kemerahan), bengkak dan penutupan luka sebagai indikator dari penelitian ini dapat dilihat pada tabel berikut.

Tabel 3. Hasil pengamatan luka yang diolesi vaseline putih (Kontrol negatif)

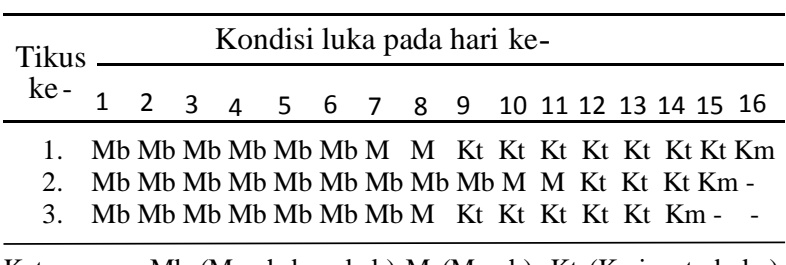

Keterangan: Mb (Merah bengkak) M (Merah), Kt (Kering terbuka) Km (Kering menutup)

Terlihat eritema (kemerahan) dan bengkak muncul pada hari pertama namun untuk waktu menghilangnya eritema untuk tiap kelompok perlakuan berbeda-beda. Untuk waktu tercepat menghilangnya eritema terdapat pada tikus ke-1 dan tikus ke-3 yaitu hari ke-9 dan terlama pada tikus ke-2 yaitu pada hari ke-12 sedangkan menghilangnya bengkak untuk waktu tercepat terdapat pada tikus ke-1 pada hari ke-7 diikuti tikus ke-3 yaitu pada hari ke-8 dan terlama pada tikus ke-2 yaitu hari ke-10

Tabel 4. Hasil pengamatan luka yang diolesi salep betadine (Kontrol positif)

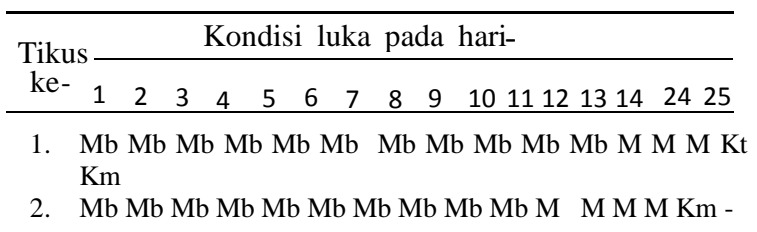

Keterangan: Mb (Merah bengkak) M (Merah), Kt (Kering terbuka) $\mathrm{Km}$ (Kering menutup) 
Waktu tercepat menghilangnya eritema (kemerahan) terdapat pada tikus ke-3 yaitu hari ke-7 dan terlama pada tikus ke-2 dan ke-3 yaitu hari ke-24. Menghilangnya bengkak untuk waktu tercepat terdapat pada tikus ke-1 yaitu hari ke-3, diikuti tikus ke-2 yaitu hari ke-11 dan terlama pada tikus ke-1 yaitu hari ke-12

Tabel 5. Hasil pengamatan luka yang diolesi salep ekstrak daun jarak pagar $10 \%$

\begin{tabular}{|c|c|c|c|c|c|c|c|c|c|c|c|c|c|}
\hline \multirow{2}{*}{$\begin{array}{c}\text { Tikus } \\
\text { ke - }\end{array}$} & \multicolumn{10}{|c|}{ Kondisi luka pada hari ke- } & \multirow[b]{2}{*}{12} & \multirow[b]{2}{*}{13} & \multirow[b]{2}{*}{14} \\
\hline & 1 & 2 & 4 & 5 & 6 & 7 & 8 & 9 & 10 & 11 & & & \\
\hline 1 & $\mathrm{M}$ & $\mathrm{Mb}$ & $\mathrm{Mb} \mathrm{Mb}$ & $\mathrm{Mb}$ & $\mathrm{Mb}$ & Mb & & $\mathrm{M}$ & $\mathrm{Kt}$ & $\mathrm{Km}$ & - & - & - \\
\hline 2 & $\mathrm{M}$ & $\mathrm{Mb}$ & $\mathrm{Mb} \mathrm{M}$ & M & $\mathrm{Kt}$ & $\mathrm{Kt}$ & $\mathrm{Kt}$ & $\mathrm{Km}$ & $n-$ & - & - & - & - \\
\hline 3 & $\mathrm{M}$ & $\mathrm{Mb}$ & $\mathrm{Mb} \mathrm{M}$ & M & $\mathrm{Kt}$ & $\mathrm{Kt}$ & $\mathrm{Km}$ & & - & - & - & - & - \\
\hline
\end{tabular}

Keterangan: Mb (Merah bengkak) M (Merah), Kt (Kering terbuka) Km (Kering menutup)

Waktu tercepat menghilangnya eritema (kemerahan) terdapat pada tikus ke-2 dan ke-3 yaitu hari ke-6 dan terlama pada tikus ke-1 yaitu hari ke-9. Menghilangnya bengkak untuk waktu tercepat terdapat pada tikus ke-2 dan ke-3 yaitu hari ke-4 dan terlama pada tikus ke-1 yaitu hari ke-6

Tabel 6. Hasil pengamatan luka yang diolesi salep ekstrak daun jarak pagar $20 \%$

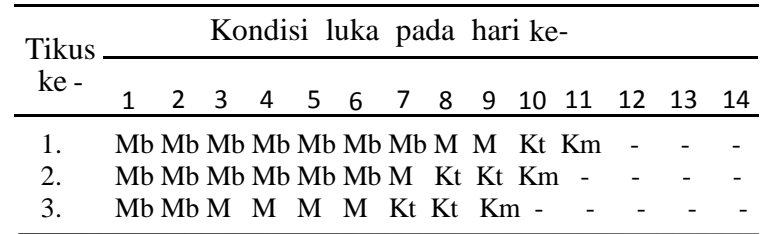

Keterangan: Mb (Merah bengkak) M (Merah), Kt (Kering terbuka) Km (Kering menutup)

Waktu tercepat menghilangnya eritema (kemerahan) terdapat pada tikus ke-3 yaitu hari ke-7, diikuti tikus ke-2 yaitu hari ke-8 dan terlama pada tikus ke-1 yaitu hari ke-10. Menghilangnya bengkak untuk waktu tercepat terdapat pada tikus ke-3 yaitu hari ke-
3, diikuti tikus ke-2 yaitu hari ke-7 dan terlama pada tikus ke-1 yaitu hari ke- 8

Tabel 7. Hasil pengamatan luka yang diolesi salep ekstrak daun jarak pagar $40 \%$

\begin{tabular}{lllllllllllllll}
\hline \multirow{2}{*}{$\begin{array}{c}\text { Tikus } \\
\text { ke }-\end{array}$} & 1 & 2 & 3 & 4 & 5 & 6 & 7 & 8 & 9 & 10 & 11 & 12 & 13 & 14 \\
\hline 1. & Mb Mb Mb Mb Mb Mb Mb M Kt Km & - & - & - & - \\
2. & $M b$ & $M$ & $M$ & $M$ & $M$ & $M$ & $M$ & $K t$ & $K m$ & - & - & - & - & - \\
3. & $M b$ & $M$ & $M$ & $M$ & $K t$ & $K m$ & - & - & - & - & - & - & - \\
\hline
\end{tabular}

Keterangan: Mb (Merah bengkak) M (Merah), Kt (Kering terbuka) Km (Kering menutup)

Waktu tercepat menghilangnya eritema (kemerahan) terdapat pada tikus ke-3, diikuti tikus ke-2 yaitu hari ke-8 dan terlama pada tikus ke-1 yaitu hari ke-9. Menghilangnya bengkak untuk waktu tercepat terdapat pada tikus ke-2 dan ke-3 yaitu hari ke-2 dan terlama pada tikus ke-1 yaitu hari ke- 8

Data dilakukan pengujian Normalitas (Shapiro Wilk) dan Homogenitas (Levene Test). Hasil uji Normalitas didapatkan nilai probabilitas kelompok $1(\mathrm{p}=1.000)$, kelompok II $(\mathrm{p}=0.107)$, kelompok III $(\mathrm{p}=1.000)$, kelompok IV ( $\mathrm{p}=0.637)$, kelompok V $(\mathrm{p}=$ 0.463 ), yang mana $p>0.05$ sehingga dapat disimpulkan bahwa populasi data terdistrbusi normal (pada lampiran 4). Hasil uji Homogenitas didapatkan nilai $\mathrm{p}=0.002<0.05$ yang berarti data tersebut tidak terdistribusi homogen dan dilanjutkan dengan uji Brown forsythe $\mathrm{F}$ yang diperoleh hasil $\mathrm{p}=0.197>$ 0.05. Selanjutnya dilakukanan analisis parametrik dengan Metode Anova. Hasil statistik dengan menggunakan Metode Anova dimana uji $\mathrm{F}$ menunjukkan nilai $\mathrm{F}$ hitung sebesar 3.536 dan $p=0.046$, sedangkan untuk nilai $\mathrm{F}$ tabel sebesar 3.48 .

Berdasarkan penelitian yang telah dilakukan didapatkan bahwa perlakuan pada kontrol positif Salep Povidone iodine 10\% (Betadine) memberikan efek penyembuhan paling lama dibandingkan dengan perlakuan 
lain. menurut Estuningtyas (2007), hal tersebut disebabkan karena efek samping dari povidone iodine yang terjadi pada tikus 1 dan tikus 2 sehingga mengakibatkan terjadinya perbedaan rerata waktu menutup luka yang jauh berbeda dengan kelompok perlakuan lain. PVT bahan yang ditambahkan ke yodium membentuk kompleks yang disebut povidone iodine yang digunakan dalam berbagai produk seperti salep yang dikenal dengan nama dagang Pyodine atau Betadine dan dapat digunakan sebagai pelindung kelembaban (Rowe dkk, 2006). Povidone iodine merupakan zat kimia yang dapat menimbulkan efek samping berupa rasa gatal, nyeri, bengkak dan dermatitis pada daerah luka, sehingga membuat luka menjadi kering. Menurut Burks (2014), salep povidone iodine berfungsi membunuh kuman, bakteri dan jamur serta virus dan tidak menyebabkan kekebalan terhadap kuman tersebut. Povidone iodine memiliki keunggulan dalam mengatur kelembaban luka (Noda dkk, 2009). Dasar salep yang digunakan dalam penelitian ini yaitu basis salep hidrokarbon. Dasar salep hidrokarbon dikenal sebagai dasar salep berlemak, antara lain vaseline putih dan vaseline kuning (Ansel, 1989). Menurut Fatimah (2017), ekstrak yang bersifat larut air akan mudah lepas dari basis hidrokarbon yang bersifat lemak dan merupakan penutup yang oklusif sehingga dapat menghidrasi kulit. Pemilihan vaseline putih sebagai basis salep dalam penelitian ini karena vaseline bertahan pada kulit untuk waktu yang lama, tidak mudah menguap keudara dan sukar dicuci sehingga memperpanjang kontak obat dengan kulit, kerjanya hanya sebagai penutup saja sifat-sifat tersebut sangat memguntungkan karena mampu mepertahankan kelembapan kulit sehingga bahan salep ini juga memiliki sifat moisturizer dan emollient (Ansel, 2008). Indikator yang digunakan dalam penelitian ini adalah dengan melihat ada tidaknya eritema (kemerahan) dan luka menutup. Eritema (kemerahan) dan pembengkakan merupakan hal pertama yang terlihat didaerah yang mengalami perandangan. Pada saat reaksi peradangan timbul, terjadi pelebaran arteriola yang mensuplai darah ke daerah perandangan (Qomariah, 2014). Berdasarkan hasil penelitian menunjukkan bahwa salep ekstrak dari daun jarak pagar memiliki khasiat lebih cepat menghilangkan eritema dan pembengkakan jika dibandingkan dengan vaseline putih (kontrol negatif) dan salep betadine (kontrol positif) hal ini terjadi karena daun jarak pagar memiliki kemampuan dalam menyembuhkan luka karena memiliki senyawa-senyawa biokatif yang terlibat dalam penyembuhan luka, menurut Sharma dkk (2012), daun jarak pagar mengandung zat-zat alkaloid, saponin, tanin, terpenoid, steroid, glikosida, senyawa fenol dan flavonoid, dimana pada fase hemostatis. Senyawa saponin diketahui dapat digunakan untuk menghentikan perdarahan yang memiliki sifat mengendapkan (precipitating) dan mengumpulkan (coagulating) sel darah merah (Okwu, 2004) dan dapat memacu pertumbuhan kolagen dalam proses penembuhan luka (Igbinosa dan Aieyegoro, 2009). Pada fase inflamasi menurut Mukherjee (2015), flavonoid, tanin, dan saponin memiliki kemampuan antimikroba berupa antibakteri dan antifungi. Senyawa alkaloid dan tritepenoid atau steroid memiliki kemampuan untuk meningkatkan sintesa kolagen yang merupakan salah satu komponen yang penting dalam penyembuhan luka. Sedangkan untuk penurunan bengkak paling lama pada kelompok II salep betadine (kontrol positif) yaitu pada hari ke 19 untuk tikus 1 dan 2 sedangkan untuk tikus 3 pada hari ke 7. 
Data penelitian yang telah didapatkan dilakukan uji statistik dengan menggunakan aplikasi SPSS versi 25 untuk menarik kesimpulan dari penelitian yang telah dilakukan dengan menggunakan metode One Way Anova dimana dilakukan uji normalitas terlebih dahulu dan uji homogenitas sebagai syarat kedua yang harus dipenuhi sebelum melakukan pengujian One Way Anova. Berdasarkan uji statistik yang dilakukan data terdistribusi normal tapi tidak homogen. Menurut Uyanto (2009), apabila data yang terdistribusi normal dan tidak homogen, maka dilakukan uji F, yaitu Brown forsythe F. Hasil yang didapat yaitu $\mathrm{p}=0.197>0.05$ sehingga data dinyatakan homogen. Selanjutnya dilakukan uji anova dimana diperoleh nilai $\mathrm{p}$ $<0.05$ sehingga H0 ditolak dan terima H1. Kemudian dilanjutkan dengan uji LSD.

Meskipun uji statistik dari LSD menunjukkan tidak ada perbedaan bermakna pada proses penyembuhan luka dari setiap konsentrasi salep ekstrak daun jarak pagar akan tetapi konsentrasi $40 \%$ yang memiliki efek menyembuhkan luka yang paling cepat jika dibandingkan dengan salep ekskrak daun jarak pagar dengan konsentrasi 10\% dan 20\%. Hal ini disebabkan karena pada salep ekstrak daun jarak pagar dengan konsentrasi $40 \%$ terkandung lebih banyak zat aktif yang dapat membantu proses penyembuhan luka lebih cepat. Menurut Ambiyani dkk (2013), dengan adanya peningkatan konsentrasi ekstrak, maka efektivitas antiluka semakin bagus.

\section{KESIMPULAN}

Berdasarkan penelitian yang telah dilakukan, Hasil uji statistik menunjukan adanya perbedaan terhadap lamanya penyembuhan luka pada tikus putih jantan galur wistar antara sediaan salep ekstrak daun jarak pagar dengan salep salep betadine dan basis salep

\section{SARAN}

Adapun saran dalam penelitian ini dapat dilakukan penelitian lebih lanjut secara mikroskopis, seperti penelitian histopatologi untuk memeriksa keadaan jaringan kulit saat setelah terjadinya luka.

\section{DAFTAR PUSTAKA}

Agbogidi, O.M., Akparobi, S.O., and Eruotor, P.G. 2013. Health and environmental benefits of Jatropha curcas linn. App Sci Rep. 1(2): 3639.

Ambiyani, W. 2013. Pemberian Salep Ekstrak Daun Mengkudu (Morinda citrifolia L) Meningkatkan Proses Regenerasi Jaringan Pada Tikus Putih Galur Wistar (Rattus norvegicus) Jantan. Universitas Undayana, Bogor.

Andiana. M. 2018. Perbedaan Efek Pemberian Getah Tanaman Yodium (Jatropha multifida), Jarak Pagar (Jatropha curcas) dan Povidone Iodine $10 \%$ terhadap Penyembuhan Luka Sayat pada Mencit (Mus musculus). [Skripsi]. Universitas Islam Negeri Sunan Ampel, Surabaya.

Anief, M. Formulasi Obat Topikal Dengan Dasar penyakit Kulit. Yogyakarta; Gajah Mada Press: 1997. 3-32.

Ansel C.H. 2008. Pengantar Bentuk Sediaan Farmasi. Universitas Indonesia Press, Jakarta.

Ansel H.C. 1989. Pengantar Bentuk Sediaan Farmasi. Universitas Indonesia Press, Jakarta.

Atik, N. and J. I. A. Rahman. 2009. Perbedaan Efek Pemberian Topikal Gel Lidah Buaya (Aleo vera L.) dengan Solusio Povidone iodine terhadap Penyembuhan Luka Sayat 
pada Kulit Mencit (Mus musculus). [Skripsi]. Unpad, Bandung.

Asadi, S. Y., Parsaei, P., Karimi, M., Ezzati, S., Zamiri, A., Mohammadizadeh, F., \& Rafieian-kopae, M. (2013). Effect of green tea (Camellia sinensis) extract on healing process of surgical wounds in rat, Int J Surg., 11 (4): $332-337$.

Backer, C.A., dan Brink, R.C.B.V.D. 1965. Flora of Java, N.V.P. Norrdhoff, Gonogen, Netherlands. Vol.II. Published Under The Auspeces of TheRijkher barium, Liaden.

Burks R. 2014. Povidone iodine solution in wound treatment. Physical therapy, 78: $212-218$.

Estuningtyas, Arif A. 2007. Farmakologi dan Terapi. Balai penerbit FKUI, Jakarta

Fatimah. Y. 2017. Pengaruh Basis Salep terhadap Sifat Fisik Sediaan Salep Ekstrak Etanolik Bonggol Pisang Ambon (Musa paradisiaca var. sapientum L.) sebagai Penyembuhan Luka Terbuka pada Tikus. [Skripsi]. Universitas Muhammadiyah, Surakarta.

Igbinosa, O. O., Igbinosa E.O. And O.A. Aiyegoro. 2009. Antimicrobial ctivity and Phytochemical Screening of Steam Bark Extract from Jatropha curcas (Linn). African Journal of Pharmacy and Pharmacology 3 (2): 058-062.

Mukherjee P K. 2015. Evidance-Based Validation of Herbal medicine. Elsevier, Amsterdam.

Noda, Y., Fuji, K., dan Fuji, S. 2009. Critical Evalution of Cadexomer iodine ointment and povidone sugar ointment. Internasional Journal of Pharmaceutics, 37(2): 85-90.
Okwu DE. 2004. Phytochemicals and Vitamin Content of Indigenous Spices of Southeastern Nigeria. $J$ Sustain Agric Environ, 6 (1): 30-37.

Pusponegoro A. D. 2005. Luka Dalam Buku Ajar Ilmu Bedah Edisi ke-2. EGC, Jakarta.

Qomariah, S. 2014. Efektivitas Salep Ekatrak Batang Patah Tulang (Euphorbia tirucalli) Pada Penyambuhan Luka Sayat Tikus Putih (Rattus norvegicus). [Skripsi]. Jurusan Biologi FMIPA Universitas Negeri, Semarang.

Rahmawati I, Tiara N dan Harti A. 2009. Uji Aktivitas Antibakteri Salep Hidrokarbon Ekstrak Etil Asetat Daun Jengkol (Pithecollobium labatum Benth) terhadap Staphylococcus aureus ATCC 25923. Jurnal Farmasi Indonesia. 3 (6): 27.

Rairisti, A., Wahdaningsih, S., \& Wicaksono, A. 2014. Uji Aktivitas Ekstrak Etanol Biji Pinang (Areca catechu L.) Terhadap Penyembuhan Luka Sayat pada Tikus Putih (Rattus Norvegicus) Jantan Galur Wistar. [Skripsi]. Universitas Tanjungpura, Tanjungpura

Rowe, R.C. et Al. 2006. Handbook Of Pharmaceutical Expcipients, $5^{\text {th }}$ Ed, Pharmaceutical Press, London.

Sari dan Maulidya, 2016. Formulasi Sediaan Salep Ekstrak Etanol Rimpang Kunyit (Curcuma longa Linn). SEL. 1(3): 18

Selvaraj, D., Kotapadu, A., Sampurna, B., Balaji, P., Abraham, A. A., Kesavan, S. K., dan Krishnan, C. 2015. Detection of active constituents from the leaf extract of Lannea 
Coromandelica by GC-MS testing aand assessment of its pharmacological activity. Internasional Journal of Pharmaceutical Sciences and Research. 6 (3): 1217-1221.

Sharma, A.K., Gangwar, M., Tilak, R., Nath, G., Sinha, A.S.K., Tripathi, Y.B. dan Kumar, D. 2012. Comparative in vitro antimicrobial and phytochemical evaluation of methanolic extract of root, stem and leaf of Jatropha curcas Linn. Journal of Pharmacognosy. 4: (30) 34-40.

Sugiyono. 2018. Metode Penelitian Kuantitati Kualitatif dan $R$ dan $D$. Alfabeta. Bandung

Suharmiati dan Handayani. S. 2005. Ramuan Tradisional Untuk Keadaan Darurat di Rumah. PT AgroMedia Pustaka. Surakarta: Universitas Sebelas Maret, Sukoharjo.

Syamsuhidayat. 2000. Inventaris Tanaman Obat Indonesia. Edisi Pertama, Jakarta.

Uyanto, S. S. 2009. Pedoman Analisis Data dengan SPSS. Graha Ilmu, Yogyakarta.

Wardani. S,.dan Rachmania. R. 2017. Uji Aktivitas Ekstrak Etanol dan Ekstrak Etil Asetat Daun Sirih Merah (Piper cf. flagile. Benth) Terhadap Penyembuhan Luka Terbuka Pada Tikus. Media Farmasi. 1 (40): 45-50.

Wijaya, B. Citraningtyas G dan Wehantouw, F. 2014. Potensi Ekstrak Etanol Tangkai Daun Talas (Colocasia esculenta [L]) Sebagai Alternatif Obat Luka pada Kulit Kelinci (Oryctolagus cuniculus). Pharmacon. 3 (3): 213. 